$\sqrt{3}$

J. bio-sci. 17: 83-88, 2009

ISSN 1023-8654

http://www.banglajol.info/index.php/JBS/index

\title{
EFFECT OF CARBON SOURCES ON CELL GROWTH AND REGENERATION ABILITY IN THREE CULTIVARS OF BANANA
}

\author{
M J Hossain, M A Bari ${ }^{*}$, N A Ara, S M Shahinul Islam \\ Biotechnology Laboratory, Institute of Biological Sciences, University of Rajshahi, \\ Rajshahi-6205, Bangladesh.
}

\begin{abstract}
Context: Carbon plays a vital role in plant cell growth and regeneration in artificial media but the source of carbon deserves scientific investigation to analysis their comparative performance.

Objectives: To analyze the comparative performance of different carbon sources (glucose, sucrose and sorbitol) in cell growth and regeneration efficiency of banana (Musa spp) cultivars.

Materials and Methods: Male flowers of banana cultivars cv. Sabri, Gine and Ranginsagar were used in this experiment. Male flowers were cut into small pieces and they were transferred in petri dishes containing Murashige and Skoog media supplemented with $2 \mathrm{mg} / \mathrm{l}$ 2,4-D + 1mg/l NAA + 1mg/l IAA + $1 \mathrm{mg} / \mathrm{l}$ Biotin $+1 \mathrm{mg} / \mathrm{l}$ glutamine and $3 \%$ (w/v) different sugars: sucrose, glucose, and sorbitol singly or in combinations autoclaved in $121^{\circ} \mathrm{C}$ temperature for $20 \mathrm{~min}$. The $\mathrm{pH}$ of the medium was adjusted to 5.8 .

Results: Glucose showed the highest performance in callus induction and cell growth and 3\% glucose proved as the optimal dose in media formulation for callus induction and cell growth. Sucrose and sorbitol behaves differently in embryo formation and they produced the highest and lowest number of embryos respectively in regeneration medium. In respect of overall performance the highest percentages of shoot and root formation was obtained in the media containing $3 \%$ sucrose.
\end{abstract}

Conclusion: Glucose proved to be the best carbon source in callus induction and cell growth media.

Key words: Banana, Musa, callus, single cell, regeneration

\section{Introduction}

Plant recovery though cell culture technology offers many useful advantages towards commercial application of many biotechnological approaches. This is an important experimental technique for a lot of studies that are not possible to perform correctly from the callus culture. Such a system is capable to contributing much significant information about to build up an understanding of an organ formation or embryonic formation starting from single cell or small cell aggregates. Concentration and sources of carbon in the medium affect the photosynthetic potentiality of plants grown from single cell or cell aggregate. Hyndman et al. (1982) and Landford and Wainwright (1988) reported that high concentration of sucrose cause to reduce the photosynthetic activity and cell growth rate.

Generally saccharides are known to serve as carbon and energy source, osmotic agents, stress protestants and signal molecules in plants (Lipavsda and Lonradove 2004). Ramage and Williams (2002) have specified that species those are difficult to propagate, demonstrate that variation in hormone ratios can not be the sole mechanism in controlling in vitro developmental processes. Carbohydrate source in media plays a very basic role in peach shoot proliferation and affects on shoot growth and survival (Priyakumari et al. 2002). Sucrose (2-5\%) is the most popular carbohydrate used with tissue culture (Bridgen 1994). The cultures in standard

${ }^{*}$ Corresponding author 
media with sucrose (Ahmad et al. 2003) have a very short culture life making the working subculture period labour intensive. Data on effect of different carbon sources on sugarcane cultures gave variable culture longevity (Anonymous 2004). Carbon sources alone or in combination also affected the synthetic seed germination in eggplant (Huda et al. 2007).

This study was planned to see the comparative effect of different carbon sources on cell growth and recovery of the plants from the embryogenic calli derived from single cell or cell aggregates.

\section{Materials and Methods}

Male flowers of three cultivars of Musa spp cv. Viz. Sabri, Jin, Gine and Ranginsagar were used as experimental materials in this investigation. The initial plant material consisted of male inflorescences of banana were collected from field grown plants. Male flowers were collected from $10^{\text {th }}$ to $18^{\text {th }}$ positions of the inflorescences after 6-10 weeks of flower opening. Under a sterile condition, the outer overlapping bracts were removed and the remaining part $(2-3 \mathrm{~cm}$ in length) containing male flowers were isolated. The explants were surface sterilized in $70 \%$ ethyl alcohol for $1 \mathrm{~min}$. The male flowers were cut into small pieces and were inoculated onto semisolid MS medium supplemented with $2 \mathrm{mgl}^{-1} 2,4-\mathrm{D}+1 \mathrm{mgl}^{-1} \mathrm{NAA}+1 \mathrm{mgl}^{-1} \mid \mathrm{AA}+1 \mathrm{mgl}^{-1}$ Biotin+1mgl|-1 glutamine and $3 \%(\mathrm{w} / \mathrm{v})$ different sugars: sucrose, glucose, and sorbitol singly or in combinations. The culture dishes were incubated in total darkness at $25 \pm 2{ }^{\circ} \mathrm{C}$ temperatures for $1-2$ months.

Cell isolation and culture of isolated cells: Suspension cultures were initiated by taking $1.5 \mathrm{~g}$ of embryogenic, rapidly growing and friable calli subcultured for 34 days as an initial inoculum in $250 \mathrm{ml}$ conical flasks containing $70 \mathrm{ml}$ of MS liquid medium fortified with $2 \mathrm{mgl}^{-1}$ 2,4-D $+1 \mathrm{mgl}^{-1} \mathrm{NAA}+1 \mathrm{mgl}^{-1} \mathrm{IAA}+$ $1 \mathrm{mgl}^{-1}$ biotin $+1 \mathrm{mgl}^{-1}$ glutamine. The suspension cultures were agitated on a rotary shaker at $100 \mathrm{rpm}$. The cultures were maintained under cool white, fluorescent light with $16 \mathrm{~h}$ of photoperiod $\left(30 \mu \mathrm{E} \mathrm{m}^{-1} \mathrm{~s}^{-1}\right)$ at $25 \pm 2^{\circ} \mathrm{C}$ temperature. After 6-7 days, the isolated cells were filtered using molecular sieve of $500 \mu \mathrm{m}$ size. To observe the growth pattern of cells, $5 \mathrm{ml}$ residue cells resuspended onto the fresh MS liquid medium and dispensed the cells equally in several sterilized flasks of $250 \mathrm{ml}$ containing $70 \mathrm{ml}$ liquid medium with different carbon sources and respective hormonal concentration mentioned above. The flasks containing cells were placed on shaker with $250 \mathrm{rpm}$ and allowed the free cells to grow. For preparing growth curves of divided cells, the weights of cells presented in $5 \mathrm{ml}$ liquid medium were taken 9 times from each flask separately.

Callus induction from isolated cells and embryo formation: To obtain callus, some of the flasks with cells were kept at stationary position at $25^{\circ} \mathrm{C}$ in dark and after $47-66$ days of incubation, micro calli were appeared in the flasks. For embryo formation, the calli derived from isolated cells were sub cultured on the agarified MS medium supplemented with different carbon sources and respective hormonal concentration. After 80 110 days the embryos were appeared in the solid MS medium. The embryos showed various polarities like unipolar and bipolar. The number of embryos per callus was calculated under microscope from the beginning of embryogenesis and their average number were calculated. For shoot and root formation, the bipolar embryos were transferred in MS medium containing different carbon sources with $1 \mathrm{mgl}^{-1} \mathrm{BAP}+2 \mathrm{mgl}^{-1} \mathrm{|AA}$.

\section{Results}

Cell growth studies: The results presented in the growth curve (Fig 1.) indicated that the three cultivars like Sabri, Gine and Ranginsagar showed the different trend of cell growth in the treated media composition and their highest growths were found in glucose containing medium within 60-70 days after incubation (Plate-1). The growth of cells of all cultivars became stationary after 70 days. This result indicates that the presence of glucose in the medium stimulated the cell growth where as sucrose and sorbitol did not display any stimulating effect on cell growth medium. 
Somatic embryo formation: Embryogenic suspensions showed two morphologically distinct cells namely spherical and elongated. The spherical embryogenic cells underwent a transverse division that resulted in two-cell and four-cell stages. They further divided in a random fashion resulting in the formation of embryogenic cell clumps that are considered as proembryo-like-structure. Subsequent repeated divisions in multiple planes resulted in the formation of embryos after 100-120 days. Further transition to heart-stage and torpedo-stage somatic embryos occurred within a week thereby confirming the bipolar nature of embryos. The highest rates of embryo formation of Sabri, Gine and Ranginsagar were observed in media containing $3 \%$ sucrose $+1 \mathrm{mgl}^{-1} \mathrm{BAP}+2 \mathrm{mgl}^{-1}$ IAA (Table 1 ). The replacement of sucrose in the media by glucose or sorbitol inhibited embryogenesis.
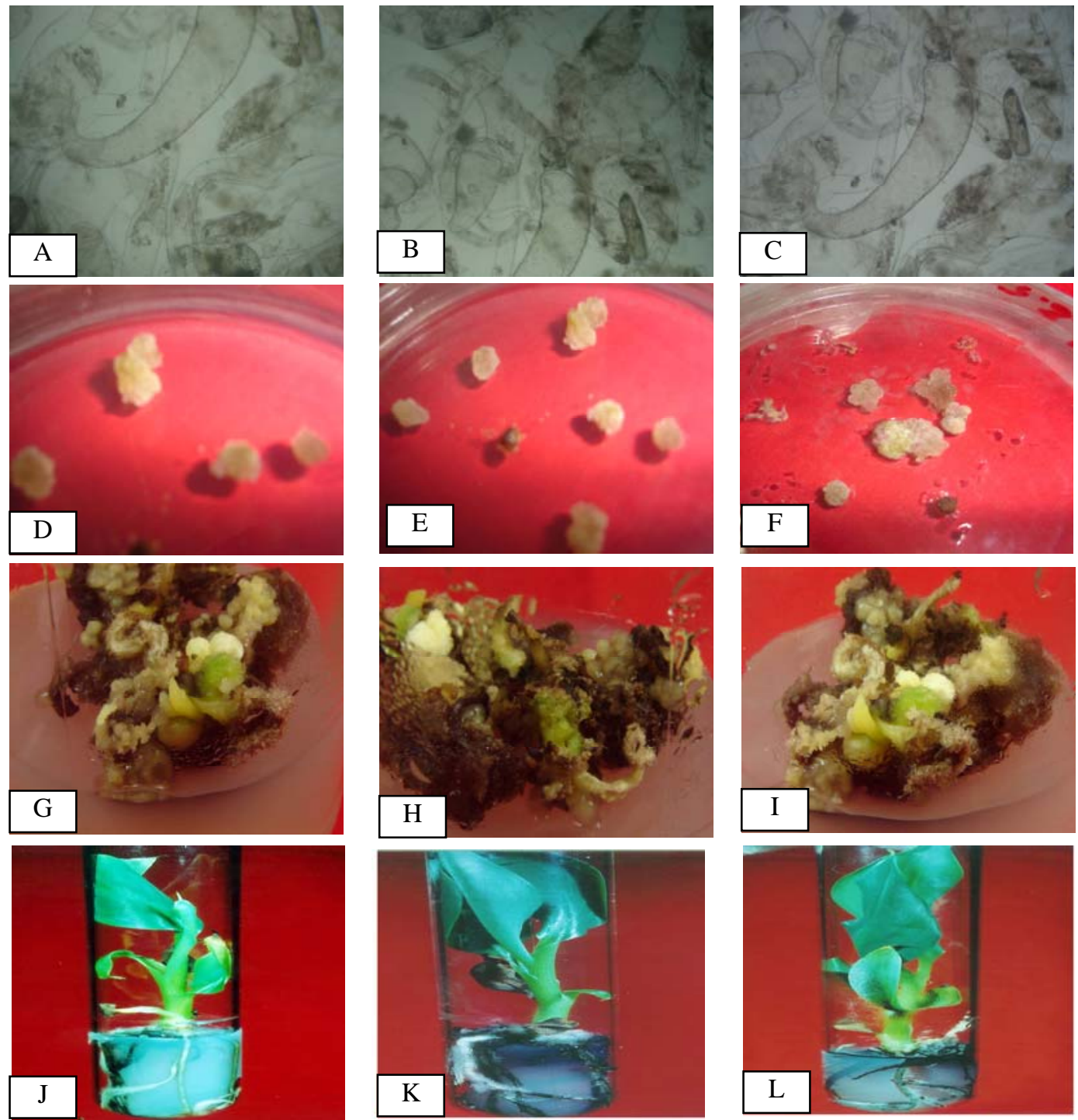

Plate 1. Complete plant production from isolated cells. Plate $A, B$ and $C$ are isolated cells, D, E and F are micro calli, G, $\mathrm{H}$ and I are calli with embryos and J, K and L are complete plants of Sabri, Gine and Ranginsagar respectively. 

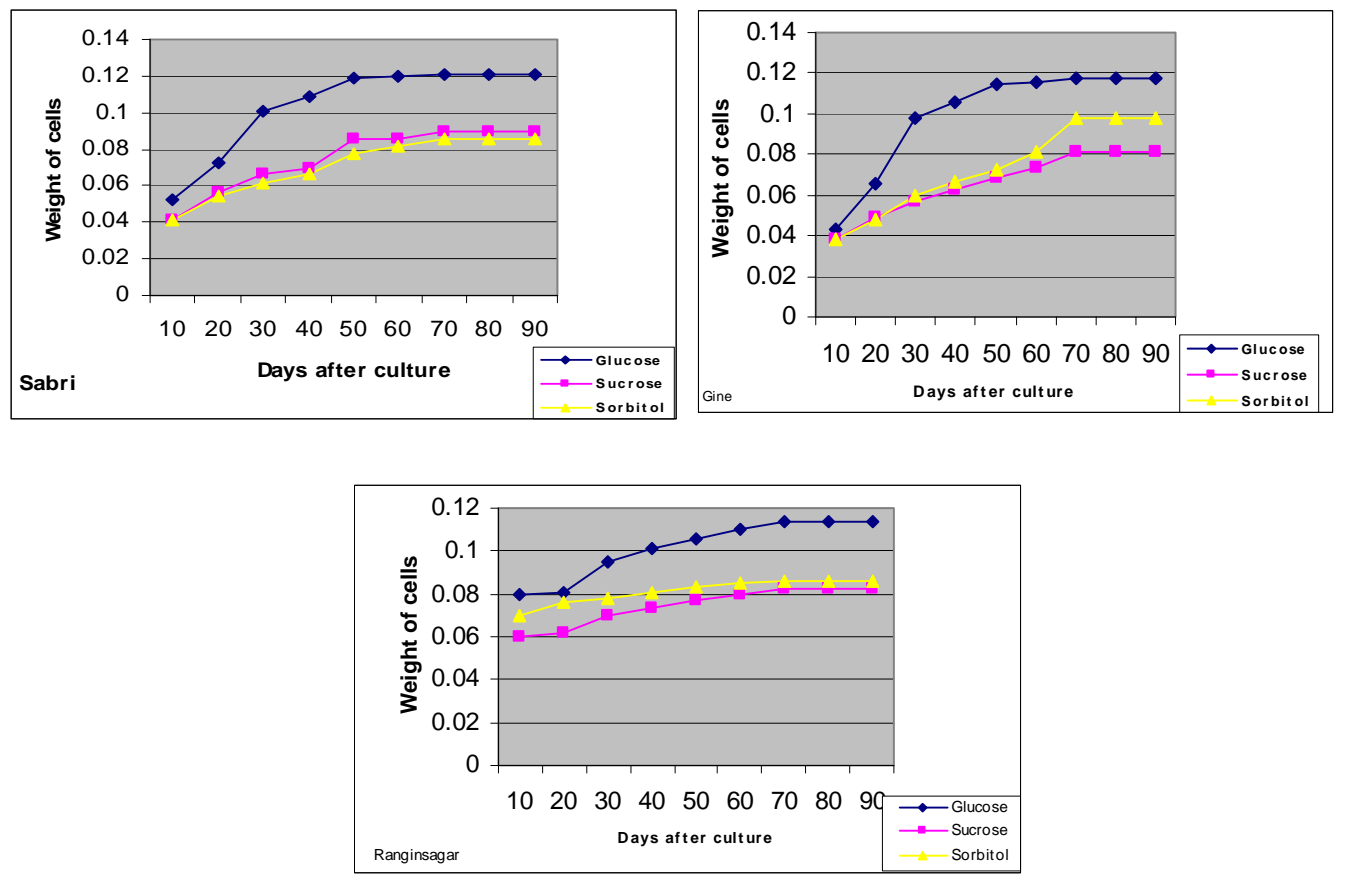

Fig 1. Showing the cell growth of three cultivars of banana in liquid MS medium

Table 1. Effect of different carbon sources employed in MS liquid medium on somatic embryo formation of the calli derived from isolated cells and root and shoot formation from the regenerated embryo.

\begin{tabular}{cccccccccc}
\hline $\begin{array}{c}\text { Carbon } \\
\text { Sources }\end{array}$ & Cultivars & $\begin{array}{c}\text { \% of cell } \\
\text { responded }\end{array}$ & $\begin{array}{c}\text { Weight/ } \\
\text { callus }\end{array}$ & $\begin{array}{c}\text { Days of } \\
\text { embryo } \\
\text { initiation }\end{array}$ & $\begin{array}{c}\text { No. of } \\
\text { embryos } \\
\text { /callus }\end{array}$ & $\begin{array}{c}\% \\
\text { root }\end{array}$ & $\begin{array}{c}\% \\
\text { shoot }\end{array}$ & $\begin{array}{c}\text { Shoot length } \\
\text { (cm) }\end{array}$ & $\begin{array}{c}\text { Root length } \\
\text { (cm) }\end{array}$ \\
\hline Glucose & S & 7.101 & 0.640 & $100-120$ & 11 & 53 & 62 & $3.10 \pm 0.49$ & $2.42 \pm 0.102$ \\
& G & 8.010 & 0.660 & $110-120$ & 10 & 46 & 71 & $3.90 \pm 0.71$ & $3.47 \pm 0.205$ \\
& R & 7.000 & 0.710 & $110-120$ & 8 & 43 & 38 & $3.80 \pm 0.24$ & $2.00 \pm 0.101$ \\
Sucrose & S & 5.230 & 0.481 & $100-120$ & 14 & 77 & 88 & $5.20 \pm 0.69$ & $4.840 \pm 0.257$ \\
& G & 6.013 & 0.521 & $110-120$ & 11 & 64 & 84 & $4.00 \pm 0.18$ & $4.19 \pm 0.102$ \\
& R & 5.301 & 0.493 & $110-120$ & 9 & 71 & 76 & $4.40 \pm 0.82$ & $3.84 \pm 0.129$ \\
& S & 6.560 & 0.583 & $100-120$ & 6 & 42 & 58 & $3.50 \pm 0.87$ & $2.65 \pm 0.122$ \\
& G & 7.413 & 0.691 & $110-120$ & 8 & 39 & 51 & $3.70 \pm 0.12$ & $3.50 \pm 0.054$ \\
& R & 6.620 & 0.525 & $110-120$ & 7 & 42 & 48 & $3.80 \pm 0.76$ & $3.18 \pm 0.150$ \\
\hline
\end{tabular}

$\mathrm{S}=$ Sabri, $\mathrm{G}=$ Gine R=Ranginsagar

Organogenesis: The highest results of shoot and root formation of Sabri, Gine and Ranginsagar were observed in media containing 3\% sucrose (Table 1). Glucose and sorbitol did not show any effective response on shoot and root formation. After the sufficient development of root the plantlets were taken and transplanted to small plastic pots containing sterilized soil. Plantlets were successfully acclimated with natural condition through gradual increase of duration of exposure to sunlight. 


\section{Discussion}

Although sucrose was used as a carbon source in most tissue culture media, a number of studies showed a positive effect of other sugars on regeneration. Glucose was the best carbon source and fructose (especially autoclaved) the worst one for shoot regeneration in Fagus sylvatica and Fagusorien talis (Cuenca and Vietez 2000), Quercus suber (Romano et al. 1995) and Prnus mume (Harada and Murai 1996). Regeneration of Hyacinthus orientalis was also more effective on medium with glucose than with sucrose (Bach and OEwiderski 2000). However, in Castanea, Juglans regia and Rosa shoots proliferation was higher on the media with either glucose or fructose rather than with sucrose (Cuenca and Vietez 2000). Monosacharides also increased somatic embryogenesis and plant regeneration: glucose in Trticum aestivum (Chu et al. 1990), fructose in Coffea cane phora (Fuentes et al. 2000) and mannose in Panax ginseng (Tang 2000). On the contrary, both types of sugars were less effective compared to sucrose in the case of Iris nigricans (Shibli and Ajlouni 2000). The autoclaved fructose was completely ineffective in rooting induction in Quercus suber (Romano et al. 1995). Such a variety of the effects of fructose on the processes described may be a result of different sensibility of particular species and types of explants to the fructose degradation products arising during autoclaving, such as 5-(hydr oxymethyl)-2-furaldehyde. Some of these products may be strongly toxic (Bogunia and Przywara 1999). Furthermore, root initiation and growth are high energy demanding processes and can occur only at the expense of available metabolic substrates. In in vitro rhizogenesis sucrose proved to be particularly useful, although glucose gave satisfactory results (Romano et al. 1995, Fotopoulos and Sotiropoulos 2004).

Sorbitol stimulates the shoot proliferation in Prunus cerasus (Borkowska and Szczerba 1995) and the somatic embriogenesis in Medicago arborea (Hita et al. 2003). On the other hand, sorbitol was completely ineffective in stimulating the shoot proliferation and the induction of roots in Quercus suber (Romano et al. 1995). We observed a similar effect in Musa spp. The negative results obtained with sorbitol showed that it is not efficiently metabolized by some species, or sorbitol in the medium is not used as carbon source at all, but regulates osmotic potencial only. However, Lemos and Baker (1998) observed that adventitious shoots were developed when the explants from internodal Annona muricata were exposed to medium with sorbitol and then transferred onto media containing sucrose or glucose. They suggested that the accumulated sorbitol led to carbon starvation in tissues lacking an enzymatic system of sorbitol conversion. Then, induction of the de novo shoots was observed on these explants. The results presented in this study do not confirm this hypothesis. Regeneration of shoot was not stimulated when they grew for 2, 4, or 6 weeks on the medium with sorbitol and then were transferred onto media containing different sugars. It is also possible that the effect of sugars on callus induction and regeneration may have the species and tissue specificity.

\section{References}

Ahmad T, Rahman HU, Ahmad Ch. MS, Laghari MH. 2003. Effect of culture media and growth regulators on micropropagation of peach rootstock GF 677. Pak J Bot 35(3), 331-338.

Anonymous 2004. Effect of carbon source for in vitro preservation of sugar cane cultures. In: Annual Report of Plant Genetic Resources Program, Institute of Agri Biotechnology and Genetic Resources, NARC, Islamabad, 2003-2004, 62pp.

Bach A, OEwiderski A. 2000. The effect of light quality on organogenesis of Hyacinthus orientalis L. in vitro. Acta Biol Cracoviensia 42, 115-120.

Bridgen MP. 1994. A review of plant embryo culture. Hort. Sci 29,1243-1245.

Borkowska B, Szczerba J. 1995. Influence of different carbon sources on invertase activity and growth of sour cherry (Prunus cerasus L.) shoot cultures. J Exp Bot 42, 911-915. 
Chu CC, Hill RD, Brule-Babel AL. 1990. High frequency of pollen embryoid formation and plant regeneration in Triticum aestvum L. on monosaccharide containing media. Plant Sci 66, 255-262. doi:10.1016/0168-9452(90)90211-6

Cuenca B, Vietez AM. 2000. Influence of carbon source on shoot multiplication and adventitious bud regeneration in in vitro beech cultures. Plant Growth Regul 32, 1-12. doi:10.1023/A:1006329510280

Fotopoulos S, Sotiropoulos TE. 2004. Invitro propagation of the peach rootstock: the effect of different carbon sources and types of sealing material on rooting. Biol Plant 48, 629-631. doi:10.1023/B:BIOP.0000047166.26010.ef

Fuentes SRL, Calheiros MBP, Manetti-Filho, Vieira LGE. 2000. The effects of silver nitrate and different carbohydrate sources on somatic embriogenesis in Coffea canephora. Plant Cell Tiss Org Cult 60, 5-13. doi:10.1023/A:1006474324652

Harada H, Murai Y. 1996. Micropropagation of Prunus mume. Plant Cell Tiss Org Cult 46, 265-267. doi:10.1007/BF02307104

Hita O, Gallego P, Villalobos N, Lanas I, Blazquez A, Mar tin JP, Fernandez J, Martin L, Guerra H. 2003. Improvement of somatic embriogenesis in Medicago arborea. Plant Cell Tiss Org Cult 72, 13-18. doi:10.1023/A:1021297902139

Huda AKMN, Rahman M, Bari MA. 2007. Effect of carbon source in Alginate Beat on synthetic seed germination in Eggplant (Solanum melongeva L.) J Plant Sci 2(5), 538-544. doi:10.3923/jps.2007.538.544

Landford PJ, Wainwright C. 1988. Influence of sucrose concentration on the Plato synthetic ability of in vitro grown rose shoots. Acta Hortic 227, 305-310.

Lemos EEP, Baker DA. 1998. Shoot regeneration in response to carbon source on internodal explants of Annona muricata L. Plant Growth Regul 25, 105-112. doi:10.1023/A:1006058301707

Lipavska H, Lonradova H. 2004. Somatic embryogenesis in conifers: The role of carbohydrate metabolism. Invitro Cell Bio.-Plant 40, 23-30. doi:10.1079/IVP2003482

Priyakumari I, Sheela VL, George S, Mirsa RL. 2002. Effect of carbon sources on in vitro shoot proliferation and rooting of gladiolus. Floricult Res Trend India. Proceedings of the National Symposium on Indian Floriculture in new milliennium, Lal-Bagh, Bangalore, Feb, 2002.

Ramage CM, Williams RR. 2002. Mineral nutrition and plant morphogenesis. Invitro Cell Biol-Plant 38, 116-124. doi:10.1079/IVP2001269

Romano A, Noronha C, Mar tins-Loucao MA. 1995. Role of carbohydrates in micropropagation of cork oak. Plant Cell Tiss Org Cult 40,159-16. doi:10.1007/BF00037670

Shibli R, Ajlouni MM. 2000. Somatic embryogenesis in the endemic black iris. Plant Cell Tiss Org Cult, 61,15-21. doi:10.1023/A:1006468122819

Tang W. 2000. High frequency plant regeneration via somatic embryogenesis and organogenesis and in vitro flowering of regenerated plantlets in Panax ginseng. Plant Cell Rep 19, 727-732. doi:10.1007/s002999900170 